\title{
Produkty tytoniowe oparte na podgrzewaniu tytoniu (heat-not-burn) a zdrowie pacjentów - opinia grupy ekspertów
}

Heat-not-burn tobacco products and patient health: Expert Group opinion

Filip M. Szymański ${ }^{1}$, Piotr Kuna ${ }^{2}$, Anna E. Płatek ${ }^{1,3}{ }^{3}$, Robert Kowalik ${ }^{1}$, Joanna Gotlib ${ }^{4}$, Krzysztof J. Filipiak ${ }^{1}$

1I Katedra i Klinika Kardiologii Warszawskiego Uniwersytetu Medycznego

${ }^{2}$ Klinika Chorób Wewnętrznych, Astmy i Alergii Uniwersytetu Medycznego w Łodzi

${ }^{3}$ Katedra i Zakład Patologii Ogólnej i Doświadczalnej Warszawskiego Uniwersytetu Medycznego

4Zakład Dydaktyki i Efektów Kształcenia Warszawskiego Uniwersytetu Medycznego

\section{STRESZCZENIE}

Nikotynizm jest jednym z uznanych i szeroko zbadanych czynników ryzyka chorób układu sercowo-naczyniowego oraz zgonu. Palenie papierosów stanowi również jeden z najistotniejszych czynników ryzyka zachorowań oraz zgonu z powodu chorób serca i naczyń krwionośnych. Mimo dostępności wielu metod wspomagających leczenie uzależnienia od tytoniu ich skuteczność pozostaje niewystarczająca. Alternatywę dla palenia papierosów mogą stanowić produkty tytoniowe oparte na podgrzewaniu tytoniu, których stosowanie może się łączyć z niższym ryzykiem sercowo-naczyniowym. W niniejszym artykule przedstawiono podsumowanie aktualnego stanu wiedzy i zaleceń polskich ekspertów w zakresie bezpieczeństwa stosowania tych produktów.

Słowa kluczowe: nikotynizm, produkty tytoniowe HnB, ryzyko sercowo-naczyniowe

Choroby Serca i Naczyń 2019, 16 (2), 135-142

\section{ABSTRACT}

Smoking, especially of cigarettes, is one of the best-recognised and most widely studied risk factors for cardiovascular disease and death. Despite the availability of many methods of counteracting tobacco addiction, their effectiveness is still insufficient. An alternative to smoking cigarettes could be tobacco products based on heating tobacco ('heat-not-burn'), the use of which may be associated with a lower cardiovascular risk. This article presents a summary of the current state of knowledge and the recommendations of Polish experts regarding the safety of these products.

Key words: cigarette smoking, heat-not-burn tobacco products, cardiovascular risk

Choroby Serca i Naczyń 2019, 16 (2), 135-142

Adres do korespondencji:

dr n. med. Anna E. Platek

Katedra i Zakład Patologii Ogólnej i Doświadczalnej

Warszawski Uniwersytet Medyczny

ul. Pawińskiego 3c, 02-097 Warszawa

e-mail: anna.platek@wum.edu.pl 


\section{WPROWADZENIE}

Nikotynizm jest jednym z uznanych i szeroko zbadanych czynników ryzyka chorób układu sercowo-naczyniowego oraz zgonu. Palenie papierosów w wytycznych towarzystw naukowych, takich jak Europejskie Towarzystwo Kardiologiczne (ESC, European Society of Cardiology), dotyczących prewencji nazywane jest „śmiertelnym uzależnieniem" [1]. Trwające blisko 50 lat badania obserwacyjne pokazały, że osoby palące (niezależnie od ilości paczkolat) umierały średnio o 10 lat wcześniej niż niepalące [2]. Kontrastuje to $\mathrm{z}$ faktem, że choroby, takie jak nadciśnienie tętnicze, powszechnie uznane za najważniejsze czynniki ryzyka sercowo-naczyniowego oraz aktywnie leczone przyczyniają się do utraty od roku do 3 lat życia [3]. Palenie odpowiada za 50\% wszystkich możliwych do uniknięcia zgonów wśród palaczy, z czego połowę stanowią zgony z przyczyn sercowo-naczyniowych, a sam współczynnik ryzyka śmierci z powodu chorób układu sercowo-naczyniowego w okresie 10 lat jest około 2-krotnie wyższy u palaczy niż w populacji niepalącej [4]. Związek palenia papierosów z omawianym ryzykiem jest wielowymiarowy i niezmiernie istotny społecznie, dlatego ciągle podejmowane są nowe działania mające na celu organicznie niekorzystnego wpływu dymu papierosowego na zdrowie.

\section{PATOFIZJOLOGICZNY ZWIĄZEK NIKOTYNIZMU Z USZKODZENIEM NARZĄDOWYM}

Mechanizmy związane z paleniem tytoniu powodujące występowanie incydentów sercowo-naczyniowych obejmują zakrzepicę, dysfunkcję śródbłonka i stan zapalny. Większość tych efektów ustępuje dość szybko po zaprzestaniu palenia, jednak wiele z nich utrzymuje się przez długie lata, istotnie wpływając na występowanie wielu typów chorób układu sercowo-naczyniowego. Trzy składniki dymu papierosowego są uważane za potencjalne czynniki przyczyniające się do chorób układu sercowo-naczyniowego. Są to nikotyna, tlenek węgla i gazy utleniające. Przeprowadzono także badania nad wielopierścieniowymi węglowodorami aromatycznymi, substancjami smolistymi i innymi składnikami dymu tytoniowego, które mogą przyczyniać się do rozwoju aterogenezy [5].

Nikotyna szybko wchłania się z dymu tytoniowego, generując stężenia we krwi tętniczej $40-100 \mathrm{ng} / \mathrm{ml}$ po wypaleniu jednego papierosa [6]. Dawka nikotyny absorbowanej z każdego papierosa wynosi zazwyczaj 1-2 mg. Chociaż po każdym papierosie występują przejściowe ostre wzrosty w stężeniu nikotyny w osoczu, to przy regularnym paleniu mają również tendencję do utrzymywania się stałe stężenia spoczynkowe [7]. Ten wzór akumulacji jest zgodny z okresem półtrwania eliminacji nikotyny wynoszącym 2 godziny [8]. Mimo to istotne stężenia nikotyny w osoczu utrzymują się nawet po całonocnej przerwie w godzinach porannych. Człowiek palący regularnie jest więc narażony na znaczną ekspozycję na nikotynę 24 godziny/dobę. Konsekwencją takiej ekspozycji jest dysfunkcja śródbłonka, zaburzenia lipidowe i insulinooporność powszechnie występujące u palaczy.

Tlenek węgla jest głównym składnikiem dymu papierosowego. U regularnych palaczy stężenie karboksyhemoglobiny wynosi średnio około 5\%, ale może wynosić 10\% lub więcej u osób palących regularnie znaczne ilości papierosów. Kontrastuje to ze stężeniem wynoszącym 0,5-2\% w przypadku osób niepalących, w zależności od stopnia narażenia na spaliny samochodowe. Tlenek węgla wiąże się gwałtownie z hemoglobiną, zmniejszając ilość hemoglobiny dostępnej do przenoszenia tlenu i hamując jego uwalnianie. Wdychanie tlenku węgla w stężeniach porównywalnych ze stężeniami występującymi u palaczy papierosów zmniejsza tolerancję wysiłku u pacjentów z dławicą piersiową, chromaniem przestankowym i przewlekłą obturacyjną chorobą płuc $[9,10]$.

Dym papierosowy dostarcza palaczowi ponadto dużego stężenia substancji chemicznych o potencjale utleniającym [11]. Substancje te obejmują: tlenki azotu i wiele różnych wolnych rodników, występujących zarówno $\mathrm{w}$ fazie gazowej, jak i smolistej w dymie papierosowym. Ekspozycja na utleniacze $\mathrm{w}$ dymie wiąże się $\mathrm{z}$ wyczerpaniem endogennych zasobów przeciwutleniaczy, objawiającym się na przykład niższym stężeniem witaminy $C$ we krwi u palaczy niż u osób niepalących [12]. Palenie papierosów zwiększa również stężenia produktów peroksydacji lipidów w osoczu i moczu [13]. Uważa się, że stres oksydacyjny przyczynia się do wielu potencjalnych mechanizmów odpowiedzialnych za powstawanie chorób układu sercowo-naczyniowego, w tym zapalenia, dysfunkcji śródbłonka, zaburzeń lipidowych (oksydacja lipoprotein o niskiej gęstości [LDL, low-density lipoprotein]) i aktywacji płytek krwi [14]. Inne substancje zawarte w dymie tytoniowym, takie jak wielopierścieniowe węglowodory aromatyczne występujące we frakcji smołowej w dymie papierosowym, w modelach eksperymentalnych wykazują natomiast wpływ na przyspieszenie rozwoju miażdżycy. 
Wiele z opisanych powyżej efektów zdrowotnych w ogromnej mierze zależy od drogi, jaką nikotyna dostarczana jest do organizmu, oraz sposobu uwalniania nikotyny. Sprawia to, że niektóre produkty tytoniowe są znacznie mniej szkodliwe od innych. W związku z tym opracowano liczne rozwiązania oraz alternatywne formy podaży nikotyny mające na celu redukcję niekorzystnego wpływu palenia papierosów na zdrowie.

\section{MOŻLIWE FORMY TERAPII UZALEŻNIENIA OD NIKOTYNY}

Wyniki badania wskazują na to, że nieco mniej niż połowa palaczy będzie palić aż do śmierci. Około 70\% osób palących papierosy deklaruje chęć rzucenia nałogu w przyszłości, a około $40 \%$ próbowało rzucić palenie przynajmniej raz w ciągu roku poprzedzającego badanie. Statystyki świadczą jednak o tym, że jedynie 2-3\% populacji udaje się na stałe rzucić palenie [15]. Zmniejszenie liczny wypalanych papierosów również nie przyczynia się do poprawy parametrów zdrowotnych. Nawet umiarkowane i rzadkie palenie papierosów powoduje podwyższenie ryzyka sercowo-naczyniowego [16]. Choć liczba osób palących systematycznie się zmniejsza w Europie, to nikotynizm pozostaje bardzo powszechny, a co istotniejsze - jego występowanie wzrasta wśród kobiet, nastolatków i dzieci [17]. W badaniu EUROASPIRE IV prowadzonym wśród pacjentów z chorobą układu sercowo-naczyniowego $16 \%$ osób paliło papierosy po średnim czasie obserwacji 16 miesięcy od incydentu wieńcowego, a prawie połowa uczestników była aktywnymi palaczami w czasie incydentu wieńcowego [18].

Wytyczne wskazują na bezwzględną potrzebę zaniechania palenia, udowadniając, że medyczne programy interwencyjne mogą zwiększyć szansę na zaprzestanie palenia o około $60 \%$, zwłaszcza gdy bodziec do zerwania $\mathrm{z}$ nałogiem pojawia się w momencie diagnozowania choroby układu sercowo-naczyniowego [19]. Programy zaprzestania palenia rozpoczęte podczas przyjęcia do szpitala powinny być kontynuowane przez dłuższy czas po wypisaniu pacjenta. $\mathrm{W}$ przypadku niepowodzenia zachęt $\mathrm{i}$ interwencji motywacyjnych można pacjentom zaproponować leczenie farmakologiczne wykorzystujące preparaty nikotynozastępcze (NRT, nicotine replacement therapy), wareniklinę lub bupropion [20]. Dostępny jest również preparat złożony bupropionu z naltreksonem $\left(M y s i m b a^{\circledR}\right)$, a także preparaty pochodzenia roślinnego - wyciągi z nasion złotokapu zwyczajnego - cytizyna $\left(\right.$ Tabex $^{\circledR}$, Desmoxan $\left.^{\circledR}\right)$. Farmakoterapia w przybliżeniu podwaja szansę pacjentów na rzucenie palenia, a substancje farmakologiczne pierwszego wyboru, zatwierdzone opcje farmakoterapii, obejmują gumę nikotynową, pastylkę do ssania, plaster, aerozol do nosa i inhalator, jak również leki wymienione wyżej. Terapie drugiego rzutu (stosowane m.in. w Stanach Zjednoczonych) obejmują leki starsze, o wielu działaniach niepożądanych — nortriptylinę i klonidynę [21]. Najnowsze dane pokazują natomiast, że farmakologiczne leczenie uzależnienia od nikotyny oparte na preparatach nikotynozastępczych jest mniej skuteczne od elektronicznych papierosów [22].

Należy jednak zauważyć, że sposoby te zwiększają jedynie szansę powodzenia terapii, $\mathrm{w}$ żadnym wypadku nie zapewniając skuteczności rzucenia palenia papierosów. Część pacjentów, niezależnie od wysiłków przedstawicieli służby zdrowia i wszelakiej pomocy farmakologicznej, paliło i dalej będzie palić papierosy. U tych osób można byłoby rozważyć strategię zmniejszania narażenia na skutki palenia tradycyjnych papierosów poprzez zastosowanie bezdymnych produktów dostarczających nikotynę o obniżonym ryzyku, tak zwanych produktów heat-not-burn (HnB).

\section{PRODUKTY TYPU HEAT-NOT-BURN NA TLE KLASYCZNYCH PRODUKTÓW TYTONIOWYCH}

Produkty HnB są obecnie jednymi z nowszych rodzajów produktów tytoniowych. Heat-not-burn to urządzenia elektroniczne, które podgrzewając przetworzony tytoń, nie dopuszczają do zachodzenia procesu spalania. Mają one powodować to, że dostarczany w tym procesie do płuc aerozol zawiera istotnie mniejsze stężenia substancji toksycznych niż dym papierosowy. W Polsce zarejestrowano obecnie dwa tego typu produkty: glo (produkowane przez British American Tobacco) oraz IQOS (zaprojektowane przez Philip Morris International). Urządzenia te wyposażone są w ładowarkę, podgrzewacz oraz wkłady tytoniowe. Wsunięte do podgrzewacza wkłady ogrzewa sterowany elektronicznie element grzejny. Heat-not-burn nie są rodzajem papierosów elektronicznych (e-papierosów), które wykorzystują opary nikotyny zawieszone $\mathrm{w}$ substancjach pochłaniających wilgoć (tzw. liquidach). Stanowią nowocześniejszą i potencjalnie mniej szkodliwą formę używania tytoniu, w pewnym stopniu podobną do stosowanej w klasycznych papierosach, jednak istotnie ograniczającą emisję wielu szkodliwych substancji.

Pierwsze produkty HnB pojawiły się na rynku w 2014 roku i wówczas zaczęly zdobywać coraz większą 
popularność [23]. W tym czasie, dzięki rosnącej świadomości społecznej i zdrowotnej dotyczącej wpływu palenia na zdrowie, produkty HnB stały się obiektem kilku szerszych, rzetelnych badań naukowych, dzięki którym opisano bliżej ich wpływ na zdrowie człowieka.

Niezależne randomizowane badania kontrolne wykazały, że przejście z palenia papierosów na stosowanie produktów HnB powodowało znaczne zmniejszenie ekspozycji na potencjalnie szkodliwe substancje zawarte w dymie tytoniowym. Należy jednak zauważyć, że nie można tych wyników uogólniać na wszystkie urządzenia typu HnB, ponieważ znacząca większość z tych badań dotyczyła 3 licencjonowanych produktów [24, 25]. Z tego powodu poniższe dane należy interpretować tylko w odniesieniu do tych produktów.

W cytowanych badaniach wykazano, że jednorazowe zastosowanie produktu $\mathrm{HnB}$ dostarcza nikotynę równie szybko, jak palenie papierosów, a jednocześnie nie pozwala na osiągnięcie tak wysokiego maksymalnego stężenia, jak w przypadku papierosów oraz zmniejsza całkowitą ekspozycję na liczne związki toksyczne (m.in. akroleina, benzen, benzo(a)piren, 4-aminobifenyl, aldehyd krotonowy, toluen), zbliżając się niekiedy do wartości obserwowanych w grupie stosującej całkowitą abstynencję tytoniową (m.in. tlenek węgla, piren, akrylonitryl, aminonaftaleny). Redukcja poziomu karboksyhemoglobiny we krwi u pacjentów, którzy zastąpili palenie papierosów produktem $\mathrm{HnB}$, wynosiła po 5 dniach średnio około $50 \%$ wartości wyjściowej [24-26]. Wiązało się to z korzystnym osłabieniem chęci zapalenia kolejnego papierosa, jednak w opinii badanych pacjentów dawało mniejszy poziom satysfakcji ocenianej na podstawie kwestionariuszy niż ten obserwowany w przypadku klasycznych papierosów [27]. Powyższe obserwacje przełożyły się na zmianę nawyków włączonych do badań pacjentów. Wykazano, że zaproponowanie dotychczasowym palaczom zamiany klasycznych papierosów na produkt $\mathrm{HnB}$ powodowało ograniczenie zużycia wkładów tytoniowych o około $20 \%$ w stosunku do liczby wypalanych dziennie papierosów [28]. Włączeni do badań pacjenci chętnie kontynuowali stosowanie produktu (blisko 90\%), a odsetek osób równocześnie palących papierosy i stosujących IQOS ${ }^{\circledR}$ był niski [29].

Z punktu widzenia lekarzy praktyków zajmujących się interwencjami zdrowotnymi u pacjentów palących papierosy najważniejsza jest odpowiedź na następujące pytanie: „W jaki sposób zmniejszona ekspozycja na dym tytoniowy oraz substancje smoliste związana ze stosowaniem produktów HnB przekłada się na zdrowie i rokowanie pacjentów?". Pierwszych odpowiedzi, na razie uzyskanych $w$ krótkim czasie, na to zagadnienie dostarczyły wyniki badań przeprowadzonych in vivo u osób niepalących, palaczy papierosów oraz osób stosujących produkt $\mathrm{HnB}$.

U zdrowych ochotników badano wiele biomarkerów sercowo-naczyniowych, które są powszechnie stosowane w ocenie metabolizmu lipidów (cholesterol frakcji LDL i triglicerydy), zapalenia (fibrynogen, białko C-reaktywne oznaczane metodą wysokoczułą [hs-CRP, high-sensitivity C-reactive protein], liczba białych krwinek), stresu oksydacyjnego (8-epi-prostaglandyna F2 [8-epi-PGF2], malonodialdehyd [MDA, malonedialdehyde], oksydowane LDL [ox-LDL] i peroksydaza glutationu [GPx, glutathione peroxidas]) itp.), oraz ich potencjalny związek z paleniem tytoniu [30]. Wykazano, że palenie papierosów łączy się z istotnym wzrostem stężenia tych biomarkerów, co przekłada się na wzrost ryzyka sercowo-naczyniowego. Zamiana papierosów na produkt typu $\mathrm{HnB}$ powoduje natomiast już po 5 dniach istotne zmniejszenie stężenia biomarkerów świadczących o ekspozycji na dym papierosowy [31]. Zmiany obserwuje się przede wszystkim w klinicznie istotnych biomarkerach stresu oksydacyjnego (8-epi-PGF2 $\alpha$ ), aktywności płytek, funkcji śródbłonka, metabolizmu lipidów oraz czynności płuc (wymuszona objętość wydechowa w ciągu 1. sekundy [FEV1, forced expiratory volume in 1 second]). Co więcej, te parametry już po tak krótkim czasie stają się porównywalne do obserwowanych u pacjentów, którzy nie palą papierosów. Podobne spostrzeżenia dotyczą zawartości czynników rakotwórczych w aerozolu HnB [32]. Obserwowane wyniki badań sugerują, że przejście na produkty typu HnB u osób długotrwale palących może potencjalnie zmniejszyć niekorzystny wpływ na zdrowie konwencjonalnych papierosów. Podobne wyniki badań naukowych stały się podstawą do wprowadzenia w niektórych krajach zapisów prawnych regulujących stosowanie produktów HnB. Alternatywne produkty tytoniowe, do których są zaliczane produkty $\mathrm{HnB}$, bywają nawet określane w piśmiennictwie mianem "produktów tytoniowych obniżonego ryzyka" (RRP, reduced risk tobacco product). Ich wprowadzenie w Japonii i Korei Południowej przyczyniło się nawet do istotnego spadku sprzedaży klasycznych papierosów [33, 34]. 


\section{REGULACJE PRAWNE DOTYCZACE PRODUKTÓW TYTONIOWYCH}

Ogromne środki finansowe zainwestowano w programy prozdrowotne mające na celu redukcję narażenia na dym tytoniowy. Podejścia do omawianego zagadnienia różnią się istotnie w zależności od analizowanego kraju.

W Polsce jeszcze w latach 80 . ubegłego wieku około $40 \%$ dorosłych paliło wyroby tytoniowe, w ostatnich latach liczba ta spadła do około $24 \% \mathrm{i}$ - jak wskazują dane Głównego Inspektoratu Sanitarnego — odsetek ten od 2015 roku stabilizuje się na tym samym poziomie [35]. Jednym z istotnych czynników, które wpłynęły na taki spadek palenia tytoniu, była ustawa z 1997 roku o ochronie zdrowia przed następstwami używania tytoniu i wyrobów tytoniowych. Po jej wprowadzeniu pojawił się całkowity zakaz reklamowania wyrobów tytoniowych w mediach, zabroniono również palenia na terenie takich instytucji jak szpitale, zakłady pracy, środki transportu publicznego czy lokale gastronomiczno-rozrywkowe. Stosowane obecnie metody zwalczania uzależnienia od tytoniu, zgodnie z zaleceniami Światowej Organizacji Zdrowia (WHO, World Health Organization), obejmują: monitorowanie postaw wobec tytoniu, ochronę przed dymem tytoniowym, oferowanie pomocy w leczeniu uzależnienia, informowanie o ryzyku zdrowotnym związanym z używaniem tytoniu i ostrzeganie przed tym ryzykiem, eliminowanie praktyk marketingowych naruszających zakaz reklamy i promocji wyrobów tytoniowych, stymulowanie wzrostu cen wyrobów tytoniowych [36]. Obecnie Polska jest jednym z liderów wdrażania tych postulatów na świecie. Jest także jednym z liderów wprowadzania polityki antynikotynowej. Ministerstwo Zdrowia kontynuuje działania mające na celu ograniczanie palenia wyrobów tytoniowych. Ustanowiono między innymi zakaz wprowadzania do obrotu papierosów mających charakterystyczny aromat, ostrzeżenia obecne na opakowaniach papierosów oraz regulację dotyczącą papierosów elektronicznych. Dalsze działania społeczne i edukacyjne są jednak niezbędne dla zupełnego wyeliminowania dymu tytoniowego w Polsce.

Podejście do problemu palenia tytoniu na poziomie społecznym różni się istotnie pomiędzy poszczególnymi krajami. Amerykańska Agencja ds. Żywności i Leków (FDA, Food and Drug Administration) w lipcu 2017 roku zwróciła uwagę na konieczność ograniczenia stężenia nikotyny w papierosach, podkreślając jednocześnie rolę alternatywnych, przebadanych technologii dostarczających nikotynę [37]. Celem kompleksowego planu redukcji uzależnienia od nikotyny jest odzwyczajenie palaczy od wyrobów tytoniowych i doprowadzenie do zerwania z nałogiem lub skierowanie ich w stronę mniej szkodliwych, alternatywnych form nikotyny, takich jak produkty $\mathrm{HnB}$ [38].

Jednym z krajów, w którym szczególną wagę przywiązuje się do ustawodawstwa nikotynowego, jest Wielka Brytania. Wydano już dokumenty sygnowane przez takie organizacje, jak the Royal College of Physicians, House of Commons Science and Technology Committee, National Institute of Clinical Excellence, oraz naukowe ciała doradcze brytyjskiego Ministerstwa Zdrowia: Committees on Toxicity, Carcinogenicity and Mutagenicity of Chemicals in Food, Consumer Products and the Environment czy Public Health England [39-42]. Wszystkie wskazują na potrzebę wspierania długoterminowych programów badawczych, aby zapewnić, że dowody związane z oddziaływaniem produktów HnB na zdrowie nie zależą wyłącznie od wpływu na rzetelność badań przemysłu tytoniowego lub producentów e-papierosów. Organizacje te podkreślają, że redukcja ekspozycji pacjenta na związki szkodliwe płynąca ze zmiany klasycznych papierosów na produkty HnB może potencjalnie skutkować zmniejszeniem ryzyka powodowanego przez produkty tytoniowe, w kontekście chorób układu sercowo-naczyniowego oraz nowotworów, jednak musi być to przedmiotem dalszych badań. Łączy się to z faktem, że stężenie nikotyny w aerozolu licencjonowanych produktów HnB jest niższe niż w dymie papierosowym. Stwierdzono także znacząco niższe (średnio o > 90\%) stężenia kluczowych związków szkodliwych wymienianych na liście WHO [43-45]. Jak zapisano we wspomnianych dokumentach, licencjonowane, bezdymne produkty zawierające nikotynę są sposobem ograniczenia szkód powodowanych przez tytoń zarówno dla osób palących, jak i biernie narażonych na dym tytoniowy. Istotnie bezpieczniejsze niż palenie tytoniu jest używanie licencjonowanych, alternatywnych produktów zawierających nikotynę, mogących zastąpić groźny nałóg lub stać się tymczasowym pomostem do całkowitego rzucenia produktów zawierających nikotynę. Takie rozumowanie w sposób szczególny rozwiewa również etyczne wątpliwości co do udziału lekarzy w debacie nad produktami typu HnB. Medycyna już dawno zaakceptowała i z powodzeniem praktykuje na przykład stosowanie terapii metadonowej w odzwyczajaniu od ciężkich narkotyków. Per analogiam nawet najkrytyczniejsi względem jakichkolwiek produktów tytoniowych 


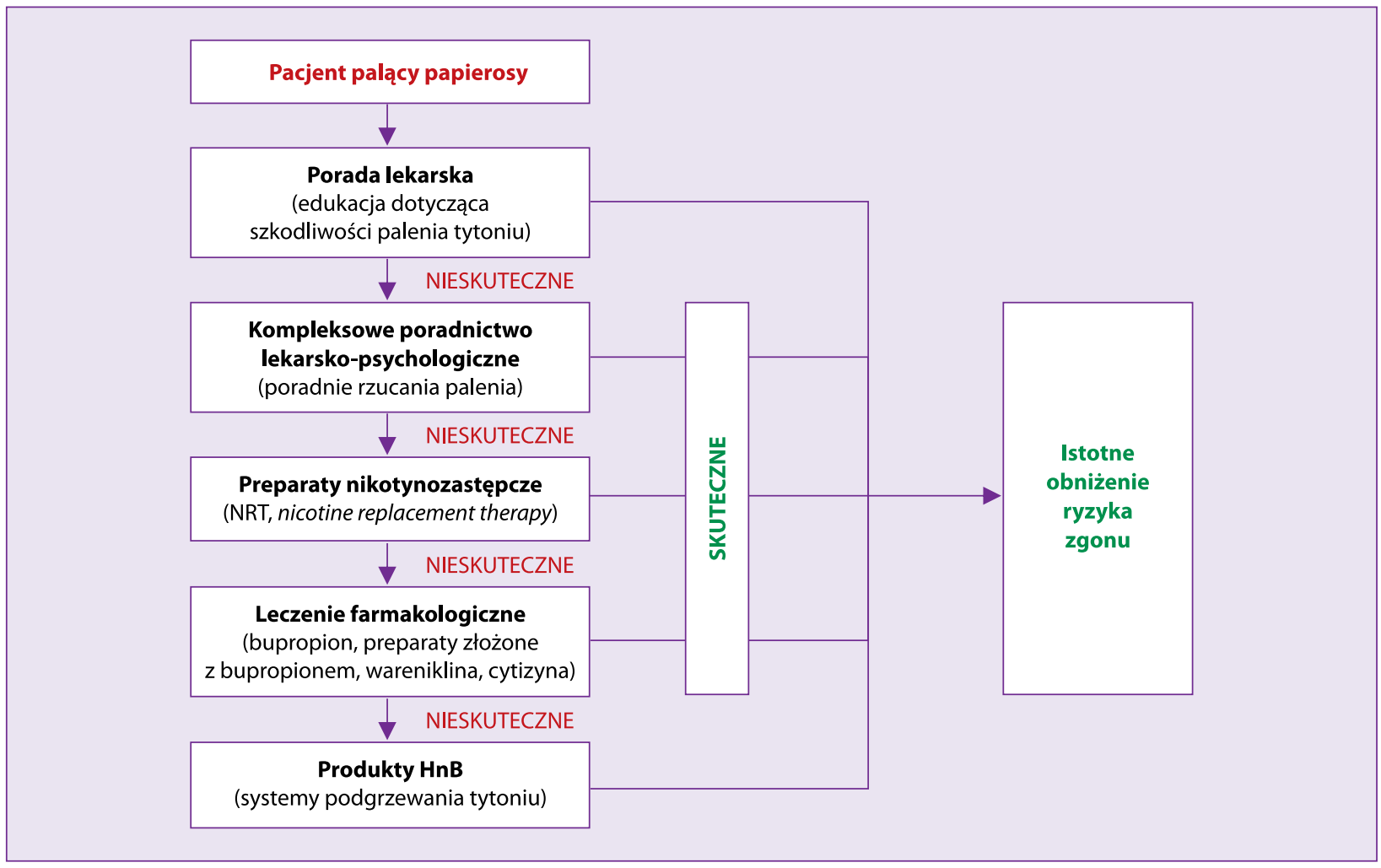

Rycina 1. Propozycja schematu interwencji mających na celu rzucenie palenia; HnB (heat-not-burn) — produkty tytoniowe oparte na podgrzewaniu tytoniu

lekarze powinni dostrzegać rolę produktów typu HnB $\mathrm{w}$ walce $\mathrm{z}$ tradycyjnymi papierosami.

Podkreśla się jednocześnie niemożność dokonania precyzyjnej kwantyfikacji redukcji ryzyka z powodu braku danych dotyczących zależności pomiędzy przyjętą dawką poszczególnych substancji szkodliwych a potencjalnymi efektami zdrowotnymi. W konsekwencji niezbędne jest kontynuowanie badań, które pozwolą dokładniej ocenić efekty stosowania produktów HnB w perspektywie długofalowej.

\section{PODSUMOWANIE}

Palenie tytoniu jest bezsprzecznie jednym z najważniejszych czynników prowadzących do rozwoju chorób układu sercowo-naczyniowego. Jest także niezależnym czynnikiem ryzyka rozwoju wielu typów nowotworów. Sprawia to, że palenie tytoniu również od wielu lat uznaje się za jeden z głównych powodów zgonu w populacji ogólnej. Każdy lekarz powinien walczyć wszelkimi dostępnymi metodami z paleniem papierosów jako przyczyną chorób serca i naczyń, płuc oraz nowotworów.

Pomimo szeroko zakrojonych działań prozdrowotnych, kampanii informacyjnych oraz rozwoju metod farmakoterapii nikotynizm pozostaje nadal nierozwiązanym problemem społecznym. Niezależnie od przedsięwziętych interwencji pewien (ciągle wysoki) odsetek osób, często mających wyjściowo podwyższone ryzyko wystąpienia chorób zależnych od ekspozycji na tytoń, nie rezygnuje z palenia. Prawdopodobnie tego trendu nie można powstrzymać żadnymi metodami. Potencjalną pomocą, nie tyle w leczeniu nikotynizmu, ile redukcji niekorzystnych skutków zdrowotnych nałogu, mogą być produkty typu HnB. Jak wykazano powyżej, ich zastosowanie przez nałogowego palacza powoduje zmniejszenie ekspozycji na szkodliwe i potencjalnie szkodliwe substancje zawarte $\mathrm{w}$ dymie tytoniowym. Obserwacje dotyczące zainteresowania pacjentów tą formą produktów tytoniowych pokazują, że zyskują one coraz większą grupę odbiorców, a sami lekarze powinni posiadać wiedzę na temat produktów HnB i ich wpływu na zdrowie [46, 47]. Wyniki jednego z badań przeprowadzonych w Polsce wykazały, że 49,7\% palaczy, którzy używali produktu $\mathrm{HnB}$, nie powróciło już do palenia papierosów. W przypadku papierosów elektronicznych odsetek ten wyniósł jedynie 16,1\% (badanie przeprowadzone w 2018 roku na zlecenie Biura do spraw Substancji 
Chemicznych — agendy Ministerstwa Zdrowia) [48]. Deklaracje badanych wskazują zatem na to, że systemy podgrzewające tytoń sprawdzają się jako alternatywa dla tradycyjnych papierosów bardziej niż papierosy elektroniczne $\mathrm{z}$ liquidem. W świetle dotychczas opublikowanych dowodów naukowych wydaje się, że produkty HnB stanowić mogą bezpieczniejszą alternatywę dla nałogowo palących pacjentów, u których kompleksowe leczenie uzależnienia od nikotyny zakończyło się niepowodzeniem. Jednocześnie niezbędne jest kontynuowanie badań ukierunkowanych na ocenę długofalowego wpływu tych produktów na zdrowie ich użytkowników.

\section{KONFLIKT INTERESÓW}

Honoraria wykładowe lub uczestnictwo w grupach doradczych następujących producentów wyrobów tytoniowych lub leków stosowanych w uzależnieniu od tytoniu: Filip M. Szymański — nie zgłoszono, Piotr Kuna - nie zgłoszono, Anna E. Płatek — nie zgłoszono, Robert Kowalik — nie zgłoszono, Joanna Gotlib — nie zgłoszono, Krzysztof J. Filipiak — Pfizer, Valeant.

\section{PIŚMIENNICTWO}

1. Piepoli MF, Hoes AW, Agewall S, et al. ESC Scientific Document Group 2016 European Guidelines on cardiovascular disease prevention in clinical practice: The Sixth Joint Task Force of the European Society of Cardiology and Other Societies on Cardiovascular Disease Prevention in Clinical Practice (constituted by representatives of 10 societies and by invited experts). Developed with the special contribution of the European Association for Cardiovascular Prevention \& Rehabilitation (EACPR). Eur Heart J. 2016; 37(29): 2315-2381, doi: 10.1093/ /eurheartj/ehw106, indexed in Pubmed: 27222591.

2. Doll R, Peto R, Boreham J, et al. Mortality in relation to smoking 50 years' observations on male British doctors. BMJ. 2004; 328(7455): 1519, doi: 10.1136/bmj.38142.554479.AE, indexed in Pubmed: 15213107.

3. Kiiskinen $U$, Vartiainen E, Puska P, et al. Long-term cost and life-expectancy consequences of hypertension. J Hypertens. 1998; 16(8): 1103-1112, indexed in Pubmed: 9794712.

4. Prescott E, Hippe M, Schnohr P, et al. Smoking and risk of myocardial infarction in women and men: longitudinal population study. BMJ 1998; 316(7137): 1043-1047, doi: 10.1136/bmj.316.7137.1043, indexed in Pubmed: 9552903.

5. Benowitz NL. Cigarette smoking and cardiovascular disease: pathophysiology and implications for treatment. Prog Cardiovasc Dis. 2003; 46(1): 91-111, indexed in Pubmed: 12920702.

6. Henningfield JE, Stapleton JM, Benowitz NL, et al. Higher levels of nicotine in arterial than in venous blood after cigarette smoking. Drug Alcohol Depend. 1993; 33(1): 23-29, indexed in Pubmed: 8370337.

7. Benowitz NL, Kuyt F, Jacob P, et al. Circadian blood nicotine concentrations during cigarette smoking. Clin Pharmacol Ther. 1982; 32(6): 758-764, doi: 10.1038/clpt.1982.233, indexed in Pubmed: 7140139.

8. Benowitz NL, Jacob P, Denaro C, et al. Stable isotope studies of nicotine kinetics and bioavailability. Clin Pharmacol Ther. 1991; 49(3): 270-277, doi: 10.1038/clpt.1991.28, indexed in Pubmed: 2007322.

9. Allred EN, Bleecker ER, Chaitman BR, et al. Short-term effects of carbon monoxide exposure on the exercise performance of subjects with coronary artery disease. N Engl J Med. 1989; 321(21): 1426-1432, doi: 10.1056/NEJM198911233212102, indexed in Pubmed: 2682242.

10. Calverley PM, Leggett RJ, Flenley DC. Carbon monoxide and exercise tolerance in chronic bronchitis and emphysema. Br Med J (Clin Res Ed). 1981; 283(6296): 878-880, doi: 10.1136/bmj.283.6296.878, indexed in Pubmed: 6793157.

11. Church DF, Pryor WA. Free-radical chemistry of cigarette smoke and its toxicological implications. Environ Health Perspect. 1985; 64: 111-126, doi: 10.1289/ehp.8564111, indexed in Pubmed: 3007083.

12. Lykkesfeldt J, Christen S, Wallock LM, et al. Ascorbate is depleted by smoking and repleted by moderate supplementation: a study in male smokers and nonsmokers with matched dietary antioxidant intakes. Am J Clin Nutr. 2000; 71(2): 530-536, doi: 10.1093/ajcn/71.2.530, indexed in Pubmed: 10648268.

13. Morrow JD, Frei B, Longmire AW, et al. Increase in circulating products of lipid peroxidation (F2-isoprostanes) in smokers. Smoking as a cause of oxidative damage. N Engl J Med. 1995; 332(18): 1198-1203, doi: 10.1056/NEJM199505043321804, indexed in Pubmed: 7700313.

14. Burke A, Fitzgerald GA. Oxidative stress and smoking-induced vascular injury. Prog Cardiovasc Dis. 2003; 46(1): 79-90, indexed in Pubmed: 12920701.

15. Taylor TLD, Bryant A, Keyse L, Joloza MT. Smoking-related behaviour and attitudes, 2005. Office for National Statistics, London 2006.

16. Prescott $\mathrm{E}$, Scharling $\mathrm{H}$, Osler $\mathrm{M}$, et al. Importance of light smoking and inhalation habits on risk of myocardial infarction and all cause mortality. A 22 year follow up of 12149 men and women in The Copenhagen City Heart Study. J Epidemiol Community Health. 2002; 56(9): 702-706, doi: 10.1136/jech.56.9.702, indexed in Pubmed: 12177089.

17. Kotseva K, Wood D, De Backer G, et al. EUROASPIRE Study Group. EUROASPIRE III: a survey on the lifestyle, risk factors and use of cardioprotective drug therapies in coronary patients from 22 European countries. Eur J Cardiovasc Prev Rehabil. 2009; 16(2): 121-137, doi: 10.1097/HJR.0b013e3283294b1d, indexed in Pubmed: 19287307

18. Kotseva K, Wood D, De Bacquer D, et al. EUROASPIRE Investigators. EUROASPIRE IV: a European Society of Cardiology survey on the lifestyle, risk factor and therapeutic management of coronary patients from 24 European countries. Eur J Prev Cardiol. 2016; 23(6): 636-648, doi: 10.1177/2047487315569401, indexed in Pubmed: 25687109.

19. Stead LF, Bergson G, Lancaster T. Physician advice for smoking cessation. Cochrane Database Syst Rev. 2008(2): CD000165, doi: 10.1002/14651858.CD000165.pub3, indexed in Pubmed: 18425860.

20. Heatherton TF, Kozlowski LT, Frecker RC, et al. The Fagerström test for nicotine dependence: a revision of the Fagerström Tolerance Questionnaire. Br J Addict. 1991; 86(9): 1119-1127, indexed in Pubmed: 1932883.

21. Barboza JL, Patel R, Patel P, et al. An update on the pharmacotherapeutic interventions for smoking cessation. Expert Opin Pharmacother. 2016; 17(11): 1483-1496, doi: 10.1080/14656566.2016.11972 03, indexed in Pubmed: 27267498.

22. Hajek P, Phillips-Waller A, Przulj D, et al. A randomized trial of E-cigarettes versus nicotine-replacement therapy. N Engl J Med. 2019; 380(7): 629-637, doi: 10.1056/NEJMoa1808779, indexed in Pubmed: 30699054

23. Simonavicius E, McNeill A, Shahab L, et al. Heat-not-burn tobacco products: a systematic literature review. Tob Control. 2018 [Epub ahead of print], doi: 10.1136/tobaccocontrol-2018-054419, indexed in Pubmed: 30181382.

24. Haziza C, de La Bourdonnaye G, Merlet S, et al. Assessment of the reduction in levels of exposure to harmful and potentially harmful constituents in Japanese subjects using a novel tobacco heating system compared with conventional cigarettes and smoking abstinence: a randomized controlled study in confinement. Regul Toxicol Pharmacol. 2016; 81: 489-499, doi: 10.1016/j.yrtph.2016.09.014, indexed in Pubmed: 27693654. 
25. Haziza C, de La Bourdonnaye G, Skiada D, et al. Evaluation of the Tobacco Heating System 2.2. Part 8: 5-Day randomized reduced exposure clinical study in Poland. Regul Toxicol Pharmacol. 2016; 81 Suppl 2: S139 -S150, doi: 10.1016/j.yrtph.2016.11.003, indexed in Pubmed: 27816672.

26. Gale N, McEwan M, Eldridge A, et al. Changes in biomarkers of exposure on switching from a conventional cigarette to tobacco heating products: a randomized, controlled study in healthy Japanese subjects. Nicotine Tob Res. 2018, doi: 10.1093/ntr/nty104, indexed in Pubmed: 29912406.

27. Cappelleri JC, Bushmakin AG, Baker CL, et al. Confirmatory factor analyses and reliability of the modified cigarette evaluation questionnaire. Addict Behav. 2007; 32(5): 912-923, doi: 10.1016/j.addbeh.2006.06.028, indexed in Pubmed: 16875787.

28. Haziza C, de La Bourdonnaye G, Merlet S, et al. Assessment of the reduction in levels of exposure to harmful and potentially harmful constituents in Japanese subjects using a novel tobacco heating system compared with conventional cigarettes and smoking abstinence: a randomized controlled study in confinement. Regul Toxicol Pharmacol. 2016; 81: 489-499, doi: 10.1016/j.yrtph.2016.09.014, indexed in Pubmed: 27693654

29. Haziza C, de La Bourdonnaye G, Donelli A, et al. Effects of switching to the Tobacco Heating System 2.2 Menthol, smoking abstinence, or continued cigarette smoking on biomarkers of exposure: a randomized, controlled, open-label, multicenter study in sequential confinement and ambulatory settings (part 1). Nicotine Tob Res. 2018; 20(2): 161-172, doi: 10.1093/ntr/ntw287, indexed in Pubmed: 28177489

30. Lüdicke F, Magnette J, Baker G, et al. A Japanese cross-sectional multicentre study of biomarkers associated with cardiovascular disease in smokers and non-smokers. Biomarkers. 2015; 20(6-7): 411-421, doi: 10.3109/1354750X.2015.1096303, indexed in Pubmed: 26616146.

31. Lüdicke F, Picavet P, Baker G, et al. Effects of switching to the Menthol Tobacco Heating System 2.2, smoking abstinence, or continued cigarette smoking on clinically relevant risk markers: a randomized, controlled, open-label, multicenter study in sequential confinement and ambulatory settings (part 2). Nicotine Tob Res. 2017; 20(2): 173-182, doi: $10.1093 / n t r / n t x 028$.

32. Mallock N, Böss L, Burk R, et al. Levels of selected analytes in the emissions of "heat not burn" tobacco products that are relevant to assess human health risks. Arch Toxicol. 2018; 92(6): 2145-2149, doi: 10.1007/s00204-018-2215-y, indexed in Pubmed: 29730817.

33. http://www.koreaherald.com/view. php?ud =20190127000090 (23.04.2019).

34. https://apps.who.int/iris/bitstream/handle/10665/273459/WHO-NMH-PND-18.7-eng.pdf (23.04.2019).
35. https://gis.gov.pl/wp-content/uploads/2018/04/Postawy-Polaków-do-palenia-tytoniu-Raport-2017.pdf (23.04.2019).

36. Streszczenie Raportu Światowej Organizacji Zdrowia WHO. www.who. un.org.pl/common/files download.php?fid=33 (23.04.2019).

37. Smith TT, Hatsukami DK, Benowitz NL, et al. Whether to push or pull? Nicotine reduction and non-combusted alternatives - two strategies for reducing smoking and improving public health. Prev Med. 2018; 117: 8-14, doi: 10.1016/j.ypmed.2018.03.021, indexed in Pubmed: 29604326.

38. Yang YT. FDA's regulatory shift on tobacco control. Prev Med. 2018; 113: 153-155, doi: 10.1016/j.ypmed.2018.02.003, indexed in Pubmed: 29866276.

39. https://assets publishing service gov uk/government/uploads/system/ /uploads/attachment_data/file/684963/Evidence_review_of_e-cigarettes_and_heated_tobacco_products (23.04.2019).

40. https://pathways.nice.org.uk/pathways/smoking-tobacco-harm-reduction-approaches (23.04.2019)

41. https://publications parliament uk/pa/cm201719/cmselect/cmsctech/505 (23.04.2019).

42. https://cot.food.gov.uk/sites/default/files/heat_not_burn tobacco statement.pdf (23.04.2019).

43. WHO Study Group on Tobacco Product Regulation: Report on the Scientific Basis of Tobacco Product Regulations. Forster M, Fiebelkorn S, Yurteri C. ed. Report on the scientific basis of tobacco product regulations. Assessment of novel tobacco heating product THP1.0. Part 3. In: Fifth report of a WHO Study Group. Technical Report Series 989. World Health Organization, Geneva 2015.

44. Comprehensive chemical characterisation of harmful and potentially harmful aerosol emissions. Regul Toxicol Pharmacol. 2018; 93: 131.

45. Schaller JP, Keller D, Poget L, et al. Evaluation of the Tobacco Heating System 2.2. Part 2: Chemical composition, genotoxicity, cytotoxicity, and physical properties of the aerosol. Regul Toxicol Pharmacol. 2016; 81 Suppl 2: S27-S47, doi: 10.1016/j.yrtph.2016.10.001, indexed in Pubmed: 27720919

46. Caputi TL, Leas E, Dredze M, et al. They're heating up: Internet search query trends reveal significant public interest in heat-not-burn tobacco products. PLoS One. 2017; 12(10): e0185735, doi: 10.1371/journal. pone.0185735, indexed in Pubmed: 29020019

47. Marynak KL, Wang TW, King BA, et al. Awareness and ever use of "heat-not-burn" tobacco products among U.S. Adults, 2017. Am J Prev Med. 2018; 55(4): 551-554, doi: 10.1016/j.amepre.2018.04.031, indexed in Pubmed: 30033025

48. https://www.chemikalia.gov.pl/monitorowanie rynku epapierosow. html (23.04.2019) 